\title{
BEBERAPA PERSPEKTIF TEORI PENYUSUNAN BAHAN AJAR KETERAMPILAN BERBAHASA INDONESIA
}

\author{
Yuni Pratiwi \\ Program Studi Sastra Indonesia \\ Fakultas Sastra Universitas Negeri Malang \\ Email: yuni_sendang@yahoo.com
}

\begin{abstract}
Facing continuous global changes, the Indonesian government views that a centralized curriculum is incapable of accommodating the development of knowledge and community needs in the local, national, and global levels. A competence-based curriculum is constructed with an expectation that in the national education system graduates have competitive and comparative advantages. The Indonesian Language subject equips students with awareness that the language is the national identity that unifies Indonesian people as a nation and simultaneously the subject develops their linguistic and communicative competence. Teachers' understanding of the scope of the competence contents and theoretical perspectives in instructional materials development affects the level of the competence attainment. Theoretical perspectives help teachers to develop instructional materials for language skills relevant to students' communicative needs in real life.
\end{abstract}

Keywords: perspective, instructional materials for the Indonesian language skills, School-Based Curriculum

\section{A. PENDAHULUAN}

Perkembangan ilmu pengetahuan dan teknologi yang berlangsung sangat cepat telah menimbulkan pengaruh perubahan yang sangat cepat pula pada berbagai aspek kehidupan. Perkembangan ini sering digambarkan oleh para peramal masa depan (futurist) sebagai abad pengetahuan (the knowledge age), karena pengetahuan akan menjadi landasan utama segala aspek kehidupan. Kalau abad 20 ditandai oleh kemajuan luar biasa di bidang manufaktur, khususnya teknologi informasi dan komputer, maka abad 21 peran manufaktur akan beralih ke sektor jasa yang berbasis pengetahuan (Ardhana, 2000:1). Jika pengetahuan menjadi tumpuhan kehidupan kehidupan, institusi pendidikan sudah seharusnya meninjau ulang tujuan dan paradigma pembelajaran yang selama ini digunakan, agar para lulusan mampu bertahan hidup pada abad 21. Kesejahteraan bangsa bukan lagi bersumber pada sumber daya alam dan modal fisik, tetapi bersumber pada modal intelektual, sosial, dan kredibilitas. Konsekuensinya, tututan untuk terus menerus memutakhirkan pengetahuan menjadi suatu keharusan. Mutu lulusan tidak cukup diukur dengan standar lokal dan nasional, tetapi juga global.

Pemerintah, melalui Pusat Kurikulum telah mengembangkan kurikulum dengan pendekatan kompetensi untuk meningkatkan kualitas dan pemerataan pendidikan nasional serta memenuhi tututan desentralisasi pendikan. Kurikulum berbasis kompetensi disusun dengan maksud agar lulusan pendidikan nasional memiliki keunggulan yang kompetetif dan komparatif. Hal ini dilakukan untuk merespon perkembangan informasi, ilmu pengetahuan, teknologi, dan seni serta melayani keanekaan kebutuhan dan kemampuan daerah. Kurikulum berbasis kompetensi menggambarkan standar minimal kualitas pendidikan yang berlaku secara nasional. 
Pembelajaran Bahasa Indonesia diarahkan untuk meningkatkan kemampuan berkomunikasi secara lisan maupun tetulis serta menumbuhkan sikap pernghargaan terhadap hasil-hasil budaya manusia Indonesia. Kurikulum nasional juga dimaksudkan untuk mengembangkan kemampuan siswa mengakses situasi multiglobal yang berorientasi pada keterbukaan dan kemasadepanan. Siswa diharapkan bersikap terbuka terhadap beragam informasi global di sekitar kehidupannya dan mampu menyaring yang bermanfaat bagi pribadi dan lingkungan sosialnya, serta menyadari eksistensi budayanya sehingga tidak tercerabut dari lingkungannya.

Salah satu faktor yang sangat menentukan keberhasilan pelaksanaan kurikulum tersebut, yaitu tersedianya bahan ajar yang memadai. Pada umumnya bahan ajar yang disajikan dalam wujud materi tercetak (printed materials) atau materi audio-visual lainnya. Hingga kini materi tercetak yang banyak digunakan adalah buku teks. Buku teks, selain menyajikan informasi teoritis tentang suatu topik, lazimnya dilengkapi dengan latihan-latihan yang dirancang dengan paradigma pembelajaran tertentu. Pemahaman terhadap standar kompetensi, kompetensi dasar, isi bidang studi, paradigma pembelajaran, dan pengukuran hasil belajar diperlukan dalam penyusunan bahan ajar. Pemahaman aspek-aspek tersebut akan memberikan gambaran tentang keluaran (outcomes), strategi belajar untuk mencapai hasil tersebut, dan indikator keberhasilan yang digunakan untuk mengukur hasil belajar siswa.

\section{B. KURIKULUM TINGKAT SATUAN PENDIDIKAN MATA PELAJARAN BAHASA INDONESIA}

Kurikulum Tingkat Satuan Pendidikan (KTSP) mata pelajaran Bahasa dan Sastra Indonesia dikembangkan dengan mempertimbangkan kedudukan dan fungsi Bahasa Indonesia sebagai bahasa nasional dan bahasa negara serta sebagai produk budaya intelektual. Pernyataan tersebut menjadi titik tolak perumusan tujuan mata pelajaran Bahasa dan Sastra Indonesia. Mata pelajaran Bahasa Indonesia bertujuan agar peserta didik memiliki kemampuan sebagai berikut.

(1) Berkomunikasi secara efektif dan efisien sesuai dengan etika yang berlaku, baik secara lisan maupun tulis

(2) Menghargai dan bangga menggunakan bahasa Indonesia sebagai bahasa persatuan dan bahasa negara

(3) Memahami bahasa Indonesia dan menggunakannya dengan tepat dan kreatif untuk berbagai tujuan

(4) Menggunakan bahasa Indonesia untuk meningkatkan kemampuan intelektual, serta kematangan emosional dan sosial

(5) Menikmati dan memanfaatkan karya sastra untuk memperluas wawasan, memperhalus budi pekerti, serta meningkatkan pengetahuan dan kemampuan berbahasa

(6) Menghargai dan membanggakan sastra Indonesia sebagai khazanah budaya dan intelektual manusia Indonesia.

Jabaran tujuan tersebut menunjukkan bahwa mata pelajaran bahasa Indonesia berkewajiban menyiapkan siswa agar memiliki kesadaran bahwa bahasa Indonesia adalah identitas nasional yang mengikat masyarakat Indoneia sebagai bangsa. Konsekuensinya, mata pelajaran Bahasa dan Sastra Indonesia sekaligus menyiapkan siswa untuk memiliki kompetensi linguistik dan komunikasi agar dapat menggunakan bahasa Indonesia dalam berbagai kepentingan.

Rumusan standar kompetensi dan kompetensi dasar dalam kurikulum mengisyaratkan bahwa mata pelajaran Bahasa Indonesia memiliki tugas yang cukup berat. Pemahaman guru terhadap substansi dan ruang lingkup isi kompetensi dan bahan ajar secara langsung akan berpengaruh terhadap derajat keberhasilan pencapaian kompetensi yang ditargetkan. Perspektif teoritik penyusunan bahan ajar dapat membantu guru menyusun bahan ajar keterampilan berbahasa yang relevan kebutuhan komunikasi siswa dalam kehidupan nyata. Hasil belajar bahasa 
Indonesia akan mempengaruhi berbagai performansi yang menggunakan bahasa sebagai media komunikasi.

\section{PERSPEKTIF PENYUSUNAN BAHAN A J A R K E T E R A M P I L A N BERBAHASAINDONESIA}

Pembelajaran bahasa Indonesia diwarnai oleh perkembangan teori yang memiliki pandangan tertentu terhadap proses pembelajaran bahasa. Teori yang dipandang sesuai sebagai perspektif proses pembelajaran bahasa Indonesia adalah perspektif konstruktivisme, whole language, komunikatif, integratif-tematis, dan kontekstual. Perspektif pembelajaran tersebut selanjutnya digunakan sebagai dasar untuk mengkaji perspektif penyusunan bahan ajar keterampilan berbahasa.

Beberapa perspektif teoritis yang dapat digunakan sebagai landasan dalam penyusunan bahan ajar pembelajarn bahasa yang akan diuraikan berikut ini mencakup perspektif konstruktivisme, whole language, komunikatif, integratif, dan belajar-mengajar kontekstual.

\section{Perspektif Konstruktivisme}

Konstruktivisme menyikapi belajar sebagai interaksi antara pembelajar dengan lingkungan kehidupan dan lingkungan sosial budayanya yang berlangsung secara dinamis. Hasil belajar yang berupa pemahaman dan keterampilan terbentuk secara akumulatif melalui kegiatan menghubungkan, membandingkan, dan memadukan butir pengalaman belajar. Hasil tersebut tidak terbentuk secara otomatis, melainkan terproses melalui kerja sama, partisipasi, dan pemberian bimbingan yang memungkinkan siswa melakukan penyesuaian, penghayataan, dan proses berpikir berkenaan dengn kenyataankenyataan yang dipelajarinya (Aminuddin, 1999).

Perspektif konstruktivisme dilandasi teeori skema yang mencetuskan gagasan bahwa inti dari pemahaman ditentukan oleh struktur kognitif yang disebut skemata (Rumelhart,
1983). Menurut teori ini, pengetahuan seseorang diorganisasikan dan disusun melalui interaksi sosial. Pengetahuan tersebut akan berubah, berkembang sesuai dengan pengalaman seseorang. Pengetahuan juga selalu dimodifikasi dan bersifat tentatif. Dengan demikian dapat disimpulkan bahwa siswa adalah pembelajar yang aktif dan konstruktif. Artinya, dalam proses belajar siswa akan terus menerus membangun makna tentang dunia berdasarkan hasil belajarnya.

B e rdasarkan perspekt if konstruktivisme di atas, penyusunan bahan ajar keterampilan berbahasa untuk mengembangkan kompetensi komunikasi dilakukan berdasarkan prinsip-prinsip berikut.

(1) Bahan ajar harus dapat mendorong terciptanya penghayatan nilai sosialkemasyarakatan secara konkrit.

(2) Bahan ajar disusun dengan memanfaatkan lingkungan keluarga dan masyarakat sebagai sumber pelajaran.

(3) Bahan ajar diarahkan untuk membentuk keterampilan belajar secara mandiri yang secara aktual dapat dimanfaatkan dalam kehidupan sehari-hari oleh siswa.

\section{Perspektif 'Whole Languaage'}

Whole Language adalah suatu filsafat (pandangan) tentang hakikat proses belajar dan bagaimana mendorong proses tersebut agar dapat berlangsung secara optimal di kelas. Whole language juga merupakan pendekatan dalam belajar bahasa (whole language approach). Whole language approach dikembangkan berdasarkan berbagai wawasan dan hasil penelitian dari berbagai bidang ilmu, antara lain pemerolehan bahasa, psikolinguistik, sosiolinguistik, kognitif dan psikologi perkembangan, antropologi, dan pendidikan. Di samping itu, whole language juga dikembangkan berdasarkan pengalaman praktis beberapa guru yang telah melaksanakan belajar-mengajar berdasarkan pandangan dan wawasan beberapa bidang ilmu tersebut.

Pandangan yang bersumber dari ilmu bahasa yang mendasari pendekataan whole 
language yakni: (1) bahasa adalah suatu sistem lambang makna yang kompleks baik dalam bentuk lisan maupun tulis yang digunakan masyarakat untuk untuk saling berkomunikasi; (2) pemakaian bahasa bersifat individual dan sosial; (3) bahasa adalah suatu supersistem yang terdiri atas subsistem-subsistem yang saling berhubungan dan membentuk hubungan interdependensi yang tidak bisa dipisahkan; dan (4) pemakaian bahasa bersifat prediktif.

Bertolak dari pandangan-pandangan di atas, dalam penyusunan bahan untuk pengembangan kompetensi komunikasi bahan ajar perlu memperhatikan hal-hal berikut .

(1) Bahan ajar disusun untuk memenuhi kebutuhaan siswa sebagai subjek belajar.

(2) Bahan ajar keterampilan berbahasa disiapkan agar siswa dapat belajar secara gradual, alamiah, tanpa banyak pengarahan dari guru .

(3) Bahan ajar tidak memisahkan konsep learning to read dan reading to learn. Sejak dini siswa dihadapkan pada teks yang predicable dan repetitive secara menyeluruh dan didorong untuk menyusun teks yang demikian pula. Oleh karena itu, pada saat siswa belajar membaca pada hakikatnya juga belajar memperoleh dan mengembangkan pengetahuan dengan bertumpu pada teks yang mereka baca.

(4) Pengembangan bahan ajar berdasarkan topik-topik pembelajaran dalam kurikulum harus berorientasi pada proses dan isi pembelajaran.

(5) Bahan ajar disiapkan agar siswa melakukan proses berpikir untuk memahami apa (misalnya hal-hal yang bersifat konseptual).dan memahami bagaimana (misalnya hal-hal yang bersifat prosedural).

\section{PerspektifKomunikatif}

Dalam perkembangan pembelajaran bahasa terdapat dua pendekatan yakni pendekatan performansi (performancedrefernced) dan pendekatan sistem (systemreferenced). Pendekatan performansi dilandasi oleh asumsi bahasa sebagai aksi, sedangkaan pendekatan sistem dilandasi asumsi bahasa sebagai sistem. Dalam pendekatan performansi, yang selanjutnya disebut pendekatan komunikatif, keterampilan berbahasa diukur secara utuh dan dalam situasi khusus dengan menggunakan kriteria performansi. Adapun dalam pendekatan sistem kemampuan bahasa diajarkan secara utuh dan diukur secara terpisah sesuai dengan sistem kebahasaan (fonologi, morfologi, sintaksis, kosa kata, dan unsur-unsur mekanik).

Dalam pendekatan komunikatif, untuk dapat berkomunikasi seseorang harus memiliki seperangkat kompetensi linguistik bahasa sasaran yang mencakup pengetahuan ortografi, leksikal, morfologi, dan semantik sebagai pengetahuan dasar. Kompetensi linguistik merupakan pengetahuan satuan-satuan linguistik, bebas dari konteks penggunaannya, bebas dari intensi, keinginan, dan kesadaran dari penggunanya. Peengetahuan yang bebas konteks tersebut belum menjamin seorang pembelajar mampu berkomunikasi. Dalam hal ini pembelajar masih memerlukan kompetensi yang lain untuk berkomunikasi, yakni kompetensi sosiolinguistik untuk memahami kesesuaian penggunaan kosa kata dan kaidah gramatika untuk berbagai kepentingan komunikasi, misalnya memilih ragam bahasa yang sesuai dengan konteks komunikasi; kompetensi kewacanaan yang berupa kemampuan mengorganisasikan gagasangagasan dalam satu tuturan yaang kohesif dan koheren; dan kompetensi strategi yakni kemampuan menggunakan strategi verbal dan non-verbal untuk mengatasi kesenjangan antara penutur dan mitra tutur.

Pandangaan di atas selanjutnya digunakan untuk mengarahkan penyusunan bahan ajar dengan cara seperti berikut.

(1) Bahan ajar memberikan kesempatan berlatih mencari dan menyampaikan informasi faktual (imparting and seeking factual information), misalnya, mengidentifikasi, melaporkaan, meringkas. 
(2) Bahan ajar memberikan kesempatan berlatih menjelaskan dan menyatakan sikap intelektual (expressing and finding out intellectual attitude), misalnya menyatakan setuju dan tidak setuju, menolak dan menerima, dan menyanggah.

(3) Bahan ajar memberikan kesempatan berlatih menyatakan sikap emosional (expressing and finding out emotional attitude), misalnya menyatakan rasa senang, tidak senang, simapati, ikut bersuka cita, ikut berduka cita, dan rasa puas.

(4) Bahan ajar memberi kesempatan berlatih menyatakan sikap moral (expressing and finding out moral attitude), misalnya meminta maaf, menyatakan penyesalan, dan penghargaan.

(5) Bahan ajar memberi kesempatan berlatih menyatakan perintah atau ajakan (getting things done), misalnya menyarankan untuk melakukan sesuatu tindakan, memerintah, dan mengingatkan.

(6) Bahan ajar melatih siswa untuk bersosialisasi (socializing), misalnya mengucapkan salam, sapaan, dan terima kasih.

\section{Perspektif Integratif}

Pendekatan integratif dapat diartikan dari dua sudut pandang. Pertama, seperti dijelaskan sebelumnya menurut pandangan whole language proses belajar bahasa akan berjalan dengan mudah dan lancar jika bahasa itu dipelajari dalam konteks yang menyeluruh dan alamiah. Dalam kenyataan pembelajaran di sekolah pada saat siswa belajar bahasa secara langsung isi dari bidang studi lain bersamasama menjadi bagian dari kurikulum secara utuh. Meskipun kurilukum tersebut tetap berfokus pada bidang studi yang dipelajari bagi siswa, akan tetapi bagi guru terdapat dua hal yang harus diperhatikan bersama-sama (double agenda), yakni aspek kebahasaan dan keterampilan berbahasa dan ketepatan isi peristiwa kebahasaa yang dipelajari.
Secara khusus dalam pembelajaran bahasa integrasi juga berlangsung dalam pembelajaran keterampilan berbahasa itu sendiri. Kegiatan keterampilan berbahasa tidak hanya melibatkan satu keterampilan berbahasa tertentu, sebab seringkali jenis keterampilan tersebut muncul secara serentak muncul dalam konteks komunikasi. Namun demikian, dalam setiap pembelajran guru harus sadar pada pentingnya pemilihan fokus keterampilan yang akan dikembangkan.

Pendekatan integratif mendorong pandangan yang baru yakni pendektan tematis. Pendekatan tematis merupakan pendekatan dalam perancangan pembelajaran yang berpusat pada satu tema. Tema memiliki fungsi menyatukan bagian-bagian pembelajaran, landasan dalam memadukan dan mengembangkan empat keterampilan berbahasa, dan mengarahkan sekuensi pembelajaran. Berdasarkan pandangan di atas, dalam pnyusunan bahan ajar tema menjadi menjadi pengikat dalam pengembangan kompetensi kebhasaan dan keterampilan berbahasa.

\section{Perspektif Belajar-Mengajar Kontekstual}

Pada hakikatnya belajar-mengajar kontekstual adalah pembelajaran yang diarahkan untuk membantu siswa menghubungkan dan mengaplikasikan pengetahuan yang telah dipelajari ke dalam konteks kehidupan yang nyata, misalnya keluarga, masyarakat, dan tempat kerja. Siswa diharapkan dapat menemukan makna dari proses belajarnya. Dalam konteks yang demikian, siswa menyadari tujuan belajarnya dan berusaha mencapai tujuan belajar tersebut dengan menghubungkan apa yang dipelajari dengan dengan pengetahuan baru secara terintegratif dan multidisiplin. Beberapa pikiran yang mendasari pendekatan ini yakni berlajar bahasa berbasis konstruktivisme; pembelajaraan berbasis tugas, pembelajaraan bahasa dipandang sebagai proses sosial sehingga siswa mempelajari norma, nilai dan pengetahuan kemasyarakatan dalam proses sosialisasi; pembelajaran berlangsung dalam 
situasi konteks fisik dan sosial yang nyata; distribusi pembelajaran dikembangkan dengan mendudukkan siswa sebagai bagian yang terintegrasi dalam proses belajar dengan berbagi tugas dan pengetahuan dengan pebelajar yang lain.

Bertolak dari pandangan tersebut, dalam penyusunan bahan ajar dikembangkan dengan menekankan pemberian kesempatan pada siswa untuk memahami, menganalisis, mengapresiasi, dan membangun makna berdasarkan bahan yang relevan dengan konteks sosial-edukasi untuk mencapai kompetensi kebahasaan dan komunikasi.

Perspektif penyusunan bahan ajar keterampilan berbahasa Indonesia yang dibahas berikut ini mencakup perspektif penyusunan bahan ajar keterampilan mendengarkan, keterampilan berbicara, keterampilan membaca, dan keterampilan menulis.

\section{Perspektif Penyusunan Bahan Ajar Keterampilan Mendengarkan}

Nunan (1999) mengibaratkan keterampilan mendengarkan seperti Cinderella, gadis impian yang menawan, tetapi dalam pembelajaran kalah bersaing dengan keterampilan berbahasa yang lain. Banyak orang masih beranggapan bahwa yang dimaksud dengan terampil berbahasa ialah mampu berbicara dan menulis. Akibatnya, kemampuan membaca dan mendengarkan sering terkesampingkan.

Menurut Rost seperti dikutip Nunan (1999:200) kemampuan mendengarkan menempati kedudukan penting dalam belajar bahasa di sekolah, karena mendengarkan memberikan input bagi pembelajar. Tanpa kemampuan mendengarkan yang memadai, pembelajar tidak akan pernah mengalami peristiwa belajar. Rost berpendapat bahwa ada tiga penalaran yang mendukung ditonjolkannya kedudukan kemampuan mendengarkan seperti tertera berikut ini.

(1) Kemampuan berbicara merupakan alat untuk berinteraksi, sebab dengan berinteraksi anak akan memperoleh pemahaman tuturan lawan bicaranya. Kegagalan dalam yang memahami tuturan lawan bicara bukanlah hambatan, bahkan menjadi dorongan bagi anak untuk belajar dan berinteraksi.

(2) Bahasa lisan yang alami memberikan tantangan bagai pembelajar untuk memahami bahasa yang didengarnya dari penutur asli.

(3) Latihan mendengarkan merupakan alat bagi guru untuk mengarahkan perhatian anak didiknya terhadap bentuk-bentuk (kosa kata, tatabahasa, dan pola-pola interaksi) dalam bahasa yang dipelajari.

Pertimbangan pedagogis yang cukup penting bagi perancang dan penulis bahan ajar adalah mempertimbangkan tingkat kesulitan tugas. Jika kompleksitas gramatika bukan satusatunya faktor yang menentukan untuk memutuskan urutan tugas dalam pembelajaran secara keseluruhan, Watson dan Smeltzer (1984) menyarankan bahwa faktor internal pembelajar seperti perhatian, motivasi, minat, dan pengetahuan tentang topik dapat menjadi pelancar bagi pendengar untuk memperoleh kesusksesan. Selain itu, faktor teks, seperti pengorganisasian teks, sekuensi, keeksplisitan, kecukupan informasi, jenis ekspresi, dan sifat isi teks (statis ataukah dinamis) perlu mendapatkan perhatian serius. Brown dan Yule 91983) menjelaskan empat faktor yang jika tidak dipertimbangkan dengan serius akan menyebabkan seseorang mengalami kesulitan dalam mendengarkan.

(1) Faktor pembicara yang meliputi jumlah pembicara, kecepatan berbicara, tipe aksen yang digunakan.

(2) Faktor pendengar yang mencakup peran pendengar (resiprokal ataukan nonresiprokal), level respon yang diharapkan, ketertarikan pendengar terhadap topik pembicaraan.

(3) Isi tuturan yang mencakup kompleksitas gramatika, kosa kata, struktur informasi, dan asumsi latar belakang pengetahuan pendengar terhadap isi tuturan. 
(4) Faktor pendukung yang berupa seberapa banyak gambar diagram, dan perangkat visual lainnya ditampilkan untuk membantu pendengar.

\section{Perspektif Penyusunan Bahan Ajar Keterampilan Berbicara}

Keterampilan berbicara membutuhkan pengetahuan tentang bagimana bunyi-bunyi artikulasi secara komprehensif, penguasaan kosa kata, dan analisis sintaksis yang memadai. Hal lain yang ikut menunjang keterampilan berbicara adalah strategi komunikasi.

Aspek lain dalam berbicara terutama berkaitan dengan perhatian pembicara, apakah pembicaraan itu bersifat spontan ataukah direncanakan. Nunan (1999) berasumsi bahwa pembicaraan cenderung bersifat spontan. Dalam terminologi fungsional, percakapan dibedakan atas percakapan yang bersifat interaksional (untuk tujuan sosial) dan transasksional (untuk memperoleh sesuatu, misalnya kesepakatan janji, informasi).

Dalam pembelajaran berbicara ada tiga faktor yang harus dipertimbangkan oleh guru dalam mendesain pengajaran. Pertama, faktor teks yang digunakan oleh pembelajar yang mencakup seberapa sederhana atau kompleks struktur isi teks, seberapa konkret atau abstrak teks yang digunakan jika dihubungkan dengan pengalaman belajar, dan seberapa besar dukungan konteks. Kedua, Faktor yang berkaitan dengan tugas berbicara yang meliputi seberapa banyak tahapan yang harus dikerjakan dalam latihan, apakah tugas itu relevan dan bermakna bagi pembelajar, seberapa banyak waktu yang tersedia, dan apakah tugas-tugas disampaikan dengan jelas. Terakhir, faktor yang berkaitan dengan pembicara (dan faktor ini yang dikontrol oleh guru) yang mencakaup faktor rasa percaya diri dan motivasi, pengetahuan sebelumnya, tingkat ketarmpilan berbahasa, dan tingkat keakraban siswa dengan tugas yang dikerjakan.

\section{Perspektif Penyusunan Bahan Ajar Keterampilan Membaca}

Kemampuan membaca tidak seperti kemampuan berbicara yang dikehendaki setiap orang untuk dipelajari. Banyak waktu, uang, dan usaha yang terbuang untuk membaca di Sekolah Dasar dan Sekolah Menengah. Pada kenyataannya, hal ini mungkin benar karena lebih banyak waktu yang digunakan untuk pembelajaran membaca dibandingkan dengan keterampilan yang lain. Salah satu tuduhan yang diarahkan pada sistem pendidikan adalah anak-anak menghabiskan waktu selama 12 tahun di sekolah dan tidak juga menjadikan mereka mahir membaca (Nunan, 1999: 249).

Rivers dan Temperly (1978:87) seperti dikutip Nunan (1999:251) mendeskripsikan tujuan membaca adalah seperti berikut.

(1) Membaca untuk mendapatkan informasi tentang topik-topik tertentu.

(2) Membaca untuk mendapatkan informasi tentang instruksi melakukan sesuatu.

(3) Membaca untuk bermain drama, game, dan bermain puzzle.

(4) Membaca untuk menjalin persahabatan melalui korespondensi atau untuk memahami surat bisnis.

(5) Membaca untuk mengetahui waktu dan tempat sutau kegiatan akan dilaksnakan atau tersedia.

(6) Membaca untuk mengetahui apa yang tengah dan telah terjadi.

(7) Membaca untuk memperoleh kegembiraan.

Dalam pembelajaran, Davies (1995) seperti dikutip Nunan (1999: 251-252) menjelaskan ciri-ciri tugas membaca yang baik, yakni: (1) menggunakan teks yang otentik dan menantang, (2) menggunakan kerangka retorika dan topik untuk memproses dan menganalisis teks, (3) sering melakukan membaca lisan yang dilakukan oleh guru atau pun siswa yang diikuti membaca diam dan membaca ulang, (4) melibatkan siswa dalam interaksi dengan teks dan siswa lain, (5) melibatkan siswa dalam analisis langsung melalui tanya jawab, (6) sering melibatkan 
transfer informasi dari teks ke tampilan visual atau representasi diagram.

Tugas membaca dapat dibedakan menjadi dua, yakni membaca rekonstuksi dan analisis. Aktivitas membaca rekonstruksi yakni siswa merekonstruksi teks yang telah dimodifikasi oleh guru dengan melengkapi kata; kalimat; merekonstruksi makna dengan membuat urutan logis dan klasifikasi; memprediksi urutan berikutnya;dan melengkapai tabel. Adapun dalam aktivitas analisis siswa membuat kategori informasi yang terdapat dalam teks dengan menandai, melabeli, memilah, merekonstruksi dalam wujud tabel dan diagram, serta klasifikasi herarkis.

Hoods dkk. Memberikan contoh mengurutkan bahan pembelajaran membaca dengan tema kesehatan yang mencerminkan urutan peristiwa sehari-hari yang telah diintegrasikan dengan pembelajaran keterampilan berbahasa yang lain seperti berikut.

(1) Mencari nomor telepon yang berhubungan dengan direktori.

(2) Menelepon untuk membuat janji.

(3) Menuliskan catatan dari hasil percakapan telepon.

(4) Mencari alamat dengan mencari direktori jalan.

(5) Memberikan informasi kepada resepsionis.

(6) Berkonsultasi dengan dokter.

(7) Membaca label obat.

(8) Menceritakan apa yang telah terjadi pada seseorang.

(9) Menelepon sekolah/tempat kerja untuk memberitahukan ketidakhadiran karena sakit.

\section{Perspektif Penyusunan Bahan Ajar Menulis}

Salah satu dari kebanyakan kontroversi dalam pembelajaran menulis adalah antara pendektan proses versus pendekatan produk. Pendekatan proses mengutamakan taha-tahap pembelajaran pada penulisa draft dan perbaikannya sebagai satu kesatuan proses menulis. Adapun pendekatan produk berorientasi pada produk akhir yang memiliki koherensi dan bebas kesalahan. Pendukung pendekatan proses mengakui bahwa belum pernah ada teks yang sempurna, namun kesipan sebuah teks diperoleh dari memproduksi, merefleksi, mendiskusikan, dan mengerjakan kembali hingga menjadi teks yang lebih baik. Adapun pendekatan produk mengutamakan pada tugas-tugas yang melibatkan pembelajar pada kegiatan meniru, menyalin, mentransformasikan model yang diberikan oleh guru atau buku teks.

Ketika melaksanakan pembelajaran menulis (dan juga berbicara) hal yang penting untuk disadari yakni perbedaan antara bahasa lisan dan tulis. Hal yang seringkali terjadi ialah, pada waktu mengajarkan menulis, siwa menulis bahasa lisan dan sebaliknya. Mengikuti pendapat Halliday (1985) yang mengatakan bahwa kekuatan menulis dalam masyarakat merupakan hasil dari perubahan budaya masyarakat yang diciptakan sebagai kebutuhan komunikasi baru. Bahasa tulis, menurut Halliday, dapat digunakan untuk kepentingan eksyen (misalnya lambang publik, label produk), untuk menyampaikan informasi (misalnya koran, majalah) dan untuk menghibur.

\section{KESIMPULAN}

Keberhasilan pelaksanaan Kurikulum mata pelajaran Bahasa dan Sastra Indonesia memerlukan dukungan tersedianya bahan ajar yang memadai. Penyusunan bahan ajar harus dilandasi dasar teori yang relevan dengan kompetensi komunikasi yang akan dikembangkan pada diri siswa. Pengembangan kompetensi komunikasi dilakukan dengan memperhatikan pengembangan kompetensi lingusitik, sosiolingustik, wacana, dan strategi komunikasi. Untuk itu, perspektif pembelajaran yang dapat digunakan adalah perpektif konstruktivisme, whole language, komunikatif, integratif, dan kontekstual. Kelima perspektif tersebut dengan didukung oleh teori pembelajaran menyimak, berbicara, membaca, dan menulis digunakan sebagai titik 
tolak penyusunan bahan ajar empat keterampilan berbahasa.

\section{DAFTAR PUSTAKA}

Aminuddin, 1999. Pembelajaran Terpadu Bahasa dan Sastra indonesia. Malang: FPBS IKIP Malang. Tidak Diterbitkan.

Ardhana, Wayan. 2000. Reformasi Pembelajaran Menghadapi Abd Pengetahuan. Makalah disajaikan dalam Seminar dan Diskusi Panel Nasional teknologi Pembelajaran V. PPS Universitas Negeri Malang, 7 Oktober 2000.

Departemen Pendidikan Nasional. KurikulumTingkaat Satuan Pendidikan Mata Pelajaran Bahasa dan Sastra Indonesia SMP/M.Ts. 2006. Jakarta: Depdiknas.

Departemen Pendidikan Nasional. KurikulumTingkaat Satuan Pendidikan Mata Pelajaran Bahasa dan Sastra Indonesia SMA/MA. 2006. Jakarta: Depdiknas.

Dubin, F. \& Olstain, E. 1986. Course Design, Developing program and material language learning. Cambridge: Cambridge University Press.

Hamka, M. 2001. Kurikulum Berbasis Kompetensi Mata Pelajaran Bahasa dan Sastra indonesia SD-SLTP-SMU. Makalah disajikan dalam seminar sehari menyongsong pemberlakukan kurikulum baru mata pelajaran Bahasa Indonesia. Jurusan Sastra Indonesia, FS Universitas Negeri Malang. Oktober 2001.
Kolb, D.A. 1984. Experiential Learning: Experience as the Source of Learning and Development. Englewood Cliffs, New Jersey: Prentice Hall.

Nunan, David. 1999. Second Language Teaching and Learning. Boston: Heinle \& Heinle Publisher.

Oxford, Rebecca L. 1990. Language Learning Strategies, What Every Teacher Should Know. Boston, Massachusetts: Heinle \& Heinle Publishers

Pappas, C.C. \& Keifer B.Z. \& Levstik L.S. 1990. An Integrated Language Perspective in the Elementary School. New York: Longman Publishers.

Rumelhart, D.E. 1980. Schemata: The Building Blocks of Cognision. In Spiro, et.all. (Ed.). Theoritical Issues in Reading Comprehension, Hillsdale, N.J.: Lawrence Erlbaum Associates, Publisher.

Semiawan, Conny, 2000 Kebijakan Pendidikan Dasar Menengah Masyarakat Indonesia Baru. Makalah disajikan dalam Konvensi Nasional Pendidikan Indonesia: Universitas Negeri Jakarta, Jakarta 19-22 September 2000.

Semiawan, C.R. dan Soedijarto (Ed.). 1991. Mencari Strategi Pengembangan Pendidikan Nsional Menjelang Abad XXI. Jakarta: PT Grasindo.

Ur, Penny. 1996. A Course in Language Teaching. Cambrige: Cambridge University Press 